\title{
PENGGABUNGAN METODE ANALYTICAL HIERARCHY PROCESS DAN MULTI-OBJECTIVE OPTIMIZATION ON THE BASIS OF RATIO ANALYSIS UNTUK PEMILIHAN PEGAWAI TERBAIK PADA KLINIK YADIKA PETUKANGAN
}

\author{
Dahlia Mariyam Ohorella ${ }^{1)}$, Deni Mahdiana ${ }^{2)}$ \\ ${ }^{1}$ Sistem Informasi, Fakultas Teknologi Informasi, Universitas Budi Luhur \\ ${ }^{1,2} \mathrm{Jl}$. Raya Ciledug, Petukangan Utara, Kebayoran Lama, Jakarta Selatan 12260 \\ E-mail : $\underline{\text { dmohorella30@gmail.com }}{ }^{1)}$, deni.mahdiana@budiluhur.ac..id ${ }^{2)}$
}

\begin{abstract}
Abstrak
Pemilihan pegawai terbaik merupakan aspek yang cukup penting di perusahaan karena dengan sumber daya manusia yang unggul dan memiliki kompetensi tinggi dapat meningkatkan produktivitas dan kinerja perusahaan serta menghasilkan pemimpin hebat di masa depan. Klinik Yadika Petukangan merupakan fasilitas pelayanan kesehatan yang menyediakan pelayanan kesehatan masyarakat. Masalah yang terjadi pada klinik yadika petukangan ialah kesulitan dalam menentukan pegawai terbaik, karena kriteria yang digunakan dalam penilaian belum ada pembobotan, belum menggunakan metode yang tepat dan masih menggunakan arsip sebagai media penyimpanan sehingga proses olah data menjadi lama. Penelitian ini bertujuan untuk mengembangkan sebuah sistem penunjang keputusan pemilihan pegawai terbaik menggunakan metode Analytical Hierarchy Process (AHP) dan metode Multi-Objective Optimization On The Basis Of Ratio Analysis (MOORA). Penelitian ini menghasilkan nilai bobot pada masing-masing kriteria yaitu kriteria kesetiaan menghasilkan bobot 7,28 \%, kriteria prestasi kerja menghasilkan bobot 7,49 \%, kriteria tanggung jawab menghasilkan bobot 12,53 \%, kriteria ketaatan menghasilkan bobot 16,56 \%, kriteria kejujuran menghasilkan bobot $27,55 \%$, kriteria kerja sama menghasilkan bobot 9,06 \%, kriteria prakarsa menghasilkan bobot 7,88 \% dan kriteria absensi menghasilkan bobot 11,65 \%, dengan hasil uji konsistensi rasio sebesar 0,0434. Hasil penelitian ini membantu dalam melakukan penilaian dalam pemilihan pegawai terbaik yang lebih mudah, cepat dan akurat.
\end{abstract}

Kata kunci: SPK, AHP, MOORA, Pemilihan Pegawai Terbaik.

\section{PENDAHULUAN}

Saat ini teknologi informasi sudah memasuki hampir kesemua bidang pekerjaan yang dilakukan oleh manusia dan berkembang sangat cepat sesuai dengan perkembangan zaman, sehingga teknologi informasi banyak diimplmentasikan dalam berbagai bidang kegiatan khususnya bidang kesehatan. Dengan adanya teknologi informasi semua pekerjaan yang dilakukan manusia dapat terselesaikan dengan cepat, mudah dan akurat.

Dalam dunia pekerjaan, [1] pemilihan pegawai terbaik merupakan salah satu aspek yang cukup penting di perusahaan karena dengan sumber daya manusia yang unggul dan memiliki kompetensi tinggi dapat meningkatkan produktivitas dan kinerja suatu perusahaan serta menghasilkan pemimpinpemimpin hebat di masa depan. Klinik Yadika Petukangan merupakan fasilitas pelayanan kesehatan yang menyediakan pelayanan kesehatan masyarakat berlokasi di Jalan Damai Raya No. 1, RT.10/RW.02, Petukangan Selatan, Pesanggrahan, Kota Jakarta Selatan, Daerah Khusus Ibu Kota Jakarta, 12270.

Dalam penelitian ini, ada beberapa kendala yang ada pada Klinik Yadika Petukangan yaitu belum adanya pemilihan pegawai terbaik karena pemilihan pegawai terbaik pada Klinik Yadika Petukangan masih menggunakan arsip sebagai media penyimpanan, belum adanya penggunaan metode yang tepat, dan belum ada pembobotan dalam kriteria yang ada pada Klinik Yadika Petukangan. Maka peneliti menggunakan metode Analytcal Hierarchy Process (AHP) dan Multi Objective Optimization On The Basis Of Ratio Analysis (MOORA). Metode metode Analytcal Hierarchy Process (AHP) untuk menentukan nilai bobot setiap kriteria. Metode Multi Objective Optimization On The Basis of Ratio Analysis (MOORA) untuk menentukan jumlah nilai alternatif dan kelebihan menggunakan metode Multi Objective Optimization On The Basis of Ratio Analysis (MOORA) ialah memiliki tingkat selektifitas, fleksibilitas, mudah dipahami dalam menentukan tujuan serta kriteria yang bertentangan dan dapat menangani seleksi proses dengan menemukan solusi optimal dari sekumpulan alternatif yang tersedia sesuai ke serangkaian tujuan.

Oleh karena itu, peneliti membuat sistem menggunakan metode Analytcal Hierarchy Process (AHP) dan Multi Objective Optimization On The Basis of Ratio Analysis (MOORA) untuk 
mempermudah dan membantu pihak Klinik Yadika Petukangan dalam pengambilan keputusan pemilihan pegawai terbaik pada klinik yadika petukangan.

Penelitian ini menghasilkan nilai bobot pada masing-masing kriteria yaitu kriteria kesetiaan menghasilkan bobot 7,28 \%, kriteria prestasi kerja menghasilkan bobot 7,49\%, kriteria tanggung jawab menghasilkan bobot $12,53 \%$, kriteria ketaatan menghasilkan bobot 16,56 \%, kriteria kejujuran menghasilkan bobot 27,55\%, kriteria kerja sama menghasilkan bobot 9,06\%, kriteria prakarsa menghasilkan bobot 7,88 \% dan kriteria absensi menghasilkan bobot 11,65 \%, dengan hasil uji konsistensi rasio sebesar 0,0434 . Hasil penelitian ini membantu dalam melakukan penilaian dalam pemilihan pegawai terbaik yang lebih mudah, cepat dan akurat.

\section{STUDI LITERATUR}

Peneliti telah melakukan penelitian terhadap jurnal [2] yang berjudul Sistem Pendukung Keputusan Pemilihan Karyawan Terbaik Menggunakan Metode Analytical Hierarchy Process (Studi Kasus Pada PT. Bando Indonesia). Tujuan utama dari penelitian ini adalah tahap penyeleksian penilaian karyawan untuk mendapatkan pnghargaan. Kriteria yang digunakan, yaitu : Hasil Checking, Jam Kerja, Shift Kerja, Data Afkir, Data Klaim. Hasil yang didapat dari penelitian ini telah dihitung berdasarkan data yang ada dan diperoleh oleh Yansen dngan jumlah nilai 0,251.

Kemudian peneliti melakukan penelitian terhadap jurnal [3] yang berjudul Sistem Pendukung Keputusan Pemilihan Guru Dan Pegawai Terbaik Menggunakan Metode MOORA. Tujuan utama dari penelitian ini ialah mengetahui proses penilaian guru dan pegawai terbaik untuk mendapatkan reward dari Kepala Sekolah. Kriteria yang digunakan ada 19, yaitu : Common Sense, Verbalisasi Ide, Sistematika Berpikir, Penalaran dan Solusi Real, Konsesntrasi, Logika Prakits, Fleksibilitas Berpikir, Imajinasi Kreatif, Antisipasi, Potensi Kecerdasan, Energi Psikis, Ketelitian dan Tanggung Jawab, Kehatihatian dan Pengendalian Rasa, Dorongan berprestasi, Vitalitas dan Perencanaan, Dominance, Influence, Steadiness, Cimplieance. Hasil yang didapat dari penelitian ini ialah Nilai terbesar yang diperoleh Adi Sitorus, S.Pd yang dipilih menjadi pegawai terbaik dengan jumlah nilai adalah 9,95.

Berikutnya peneliti telah melakukan penelitian terhadap jurnal [4] yang berjudul Sistem Pendukung Keputusan Penentuan Karyawan Terbaik Menggunakan Metode MOORA. Tujuannya untuk mengetahui pross pemilihan karyawan terbaik dengan beberapa kriteria yang digunakan yaitu,
Kedisiplinan, Kerjasama Tim, Skill, serta kualitas kerja. Hasil yang didapat dari penelitian ini ialah Nilai terbesar yang didapatkan oleh A1 sebagai karyawan terbaik dengan jumlah keseluruhan nilai yang didapat dari empat kriteria adalah 139,69.

\section{METODE PENELITIAN}

\subsection{Metode Pengumpulan Data}

Dalam penelitian ini peneliti melakukan observasi, wawancara, analisa dokumen, studi pustaka dan keusioner untuk melakukan tahap pengumpulan data pada Klinik Yadika Petukangan. Berikut merupakan penjelasannya:

Observasi yang dilakukan oleh peneliti adalah melakukan pengamatan langsung dengan hal-hal yang berkaitan sistem penunjang keputusan pemilihan pegawai terbaik pada Klinik Yadika Petukangan.

Wawancara yang dilakukan oleh peneliti dengan cara bertemu langsung dengan bagian HRD Klinik Yadika Petukangan untuk mengajukan pertanyaan yang berhubungan dengan penilaian pegawai terbaik.

Peneliti melakukan analisa dokumen yang didapat dari observasi dan wawancara dengan bagian HRD Klinik Yadika Petukangan.

Studi Pustaka yang dilakukan oleh peneliti dengan cara membaca jurnal-jurnal atau $e$-book serta referensi lainnya yang berkaitan dengan teori pemilihan pegawai terbaik, teori sistem penunjang keputusan, teori Analytical Hierarchy Process (AHP), teori Multi-Objective Optimization On The Basic of Ratio Analysis (MOORA) dan teori-teori lainnya yang berkaitan dengan pembuatan sistem penunjang keputusan ini.

Peneliti melakukan pengumpulan data dengan cara membuat kuesioner terhadap Penanggung Jawab Klinik Yadika Petukangan untuk mengetahui perhitungan nilai bobot kriteria pada pemilihan pegawai terbaik Klinik Yadika Petukangan.

\subsection{Teknik Analisis Data}

Teknik anlisa data yang digunakan oleh peneliti adalah analisis deskriptif, metode Analytical Hierarchy Process (AHP) dan metode MultiObjective Optimization On The Basic of Ratio Analysis (MOORA). Analisis deskriptif dilakukan untuk menyajikan rangkuman yang diperoleh dari hasil survei. Metode Analytical Hierarchy Process (AHP) digunakan untuk menentukan pembobotan pada setiap kriteria dan metode Multi-Objective Optimization On The Basic of Ratio Analysis (MOORA) digunakan untuk menentukan perangkingan pemilihan pegawai terbaik pada Klinik Yadika Petukangan. 


\subsection{Komponen Sistem Penunjang}

\section{Keputusan}

Aplikasi Sistem Penunjang Keputusan yang dibuat oleh peneliti terdiri dari beberapa subsystem, yaitu Data Management Subsystem, Model Management Subsystem dan User Interface Subsystem. Dari beberapa subsystem tersebut dapat digambarkan pada Gambar 1 sebagai berikut :

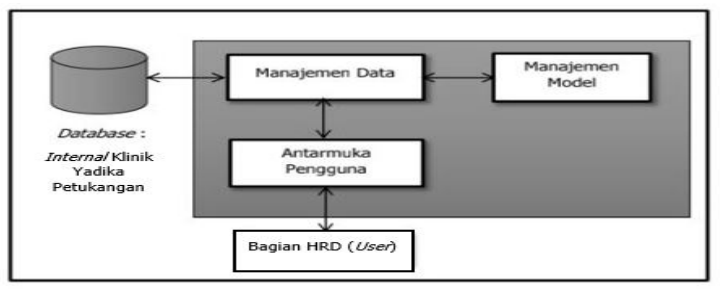

Gambar 1. Komponen Sistem Penunjang Keputusan

\section{HASIL DAN PEMBAHASAN}

\subsection{Profil Organisasi}

Yayasan Abdi Karya didirikan pada tanggal 14 Februari 1976 oleh DR. Sutan Raja Darianus Lungguk Sitorus dan Ny. Luceria Siagian, B.Sc keduanya adalah swasta bertempat tinggal di Jakarta. Akte Pendirian Yayasan dibuat oleh Notaris Willy Silitonga dengan No. 14 tanggal 14 Februari 1976 dan kemudian diubah/disempurnakan dengan Akte Notaris No.164 pada tanggal 29 November 1983 oleh Notaris yang sama.

Klinik Yadika Petukangan diresmikan pada tanggal 31 Mei 2003 dan beroperasi sejak tanggal 1 Juni 2003. Klinik Yadika Petukangan berlokasi di Jl. Damai Raya No. 1, RT 010/005, Petukangan Selatan, Pesanggrahan, Jakarta Selatan. Saat ini Klinik Yadika Petukangan dipimpin oleh dr. Prihadi Gunawan, MMRS.

\subsection{Analisa Masalah}

Fishbone Diagram atau diagram tulang ikan, [5] juga disebut sebagai diagram ishikawa yang dibuat oleh jepang. Fishbone Diagram terdiri dari garis horizontal utama dimana garis kecil yang bercabang garis diagonal utama. Hal ini membuat tampilan grafik seperti tampilan ikan. Tulang ikan merupakan penyebab dari akibat dalam situasi dimana diperlukan untuk memecahkan masalah produksi atau dilema lainnya.

Dalam menganalisa masalah pada pemilihan pegawai terbaik Klinik Yadika Petukanganm peneliti menggunakan fishbone diagram untuk menganalisa masalah dapat dilihat pada Gambar 2 sebagai berikut:

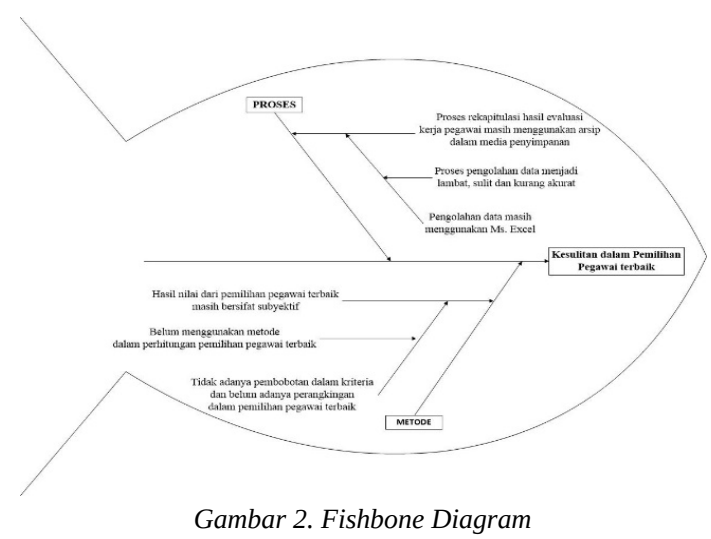

Berikut merupakan penjelasan pada Fishbone Diagram dari setiap aspek permasalahan :

a. Metode

Permasalahan pada faktor metode adalah Penanggung Jawab Klinik Yadika Petukangan kesulitan dalam pemilihan pegawai terbaik Klinik Yadika Petukangan disebabkan karena hasil nilai dari pemilihan pegawai terbaik masih bersifat subyektif disebabkan tidak adanya pembobotan dalam kriteria dan belum adanya perangkingan dalam pemilihan pegawai terbaik Klinik Yadika Petukangan disebakan belum menggunakan metode dalam perhitungan pemilihan pegawai terbaik Klinik Yadika Petukangan.

b. Proses

Permasalahan pada faktor proses adalah Penanggung Jawab Klinik Yadika Petukangan kesulitan dalam pemilihan pegawai terbaik Kliik Yadika Petukangan disebabkan proses rekapitulasi hasil evaluasi kerja pegawai masih menggunakan arsip dalan media penyimpanan disebabkan pengolahan data masih menggunakan microsoft excel disebabkan proses pengolahan data menjadi lambat, sulit dan kurang akurat.

\subsection{Proses Bisnis}

Proses pemilihan pegawai pada klinik yadika petukangan ditetapkan sebanyak 2 kali dalam setahun dan proses penilaian dilakukan oleh masingmasing koordinator. Kegiatan penilaian pegawai klinik yadika petukangan berlaku selama 1 (satu) tahun setelah diangkat menjadi pegawai tetap di klinik. Penilaian pegawai dibagi menjadi dua, yaitu penilaian pegawai untuk kenaikkan gaji dan penilaian pegawai untuk kenaikkan golongan. Penjadwalan penilaian pegawai pada klinik dilihat dari tahun masuknya pegawai atau pertama kali pegawai bekerja.

Proses penilaian pegawai, setiap koordinator menilai stafnya dengan mengisi form penilaian secara manual dan form penilaian diserahkan kepada bagian HRD. Lalu, bagian HRD melakukan rekapitulasi penilaian pegawai. Setelah itu bagian 
HRD mengadakan rapat dan menanyakan kembali kepada koordinator mengenai hasil penilaian pegawai yang telah dilakukan oleh koordinator. Bagian HRD akan melihat batasan minimal penilaian pegawai klinik berdasarkan dari pusat atau yayasan, apakah tepat menerima kenaikan gaji/golongan. Jika penilaian diatas batas minimal maka pegawai akan memasuki tahap selanjutnya. Jika penilaian dibawah batas minimal maka akan ditolak dan melakukan penilaian kembali untuk tahun berikutnya. Setelah rapat penilaian pegawai selesai dengan setiap koordinator, bagian HRD melakukan rekapitulasi penilaian pegawai.

Kemudian, diberikan kepada penanggung jawab klinik. Setelah itu penanggung jawab klinik akan berdiskusi, menanyakan kembali kepada bagian HRD mengenai penilaian pegawai dan membuat keputusan. Jika penilaian pegawai per individu tidak sesuai maka pegawai tersebut melakukan penilaian kembali untuk tahun berikutnya, apabila penilaian pegawai per individu sesuai maka akan di terima. Lalu bagian HRD akan membuat laporan kembali sesuai dengan keputusan penanggung jawab klinik. Kemudian, laporan hasil keputusan penilaian pegawai diberikan kepada penanggung jawab klinik.

Gambar 3 merupakan activity diagram yang diambil dari proses bisnis Klinik Yadika Petukangan sebagai berikut :

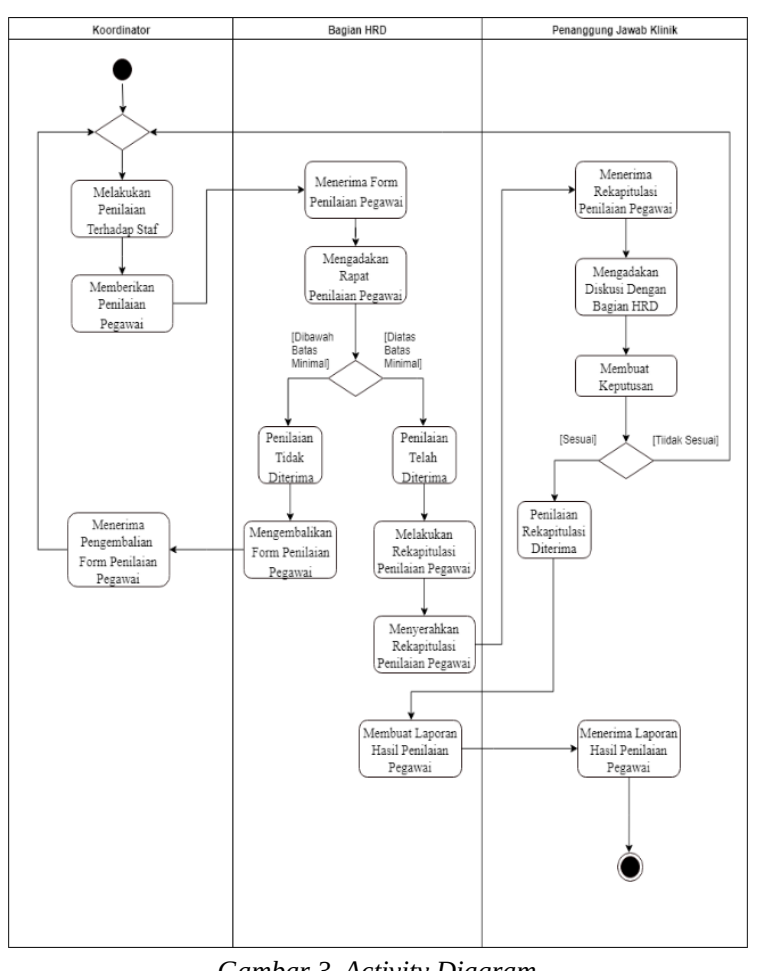

\subsection{Metode Analytical Hierarchy Process}

(AHP)

Metode Analytical Hierarchy Process (AHP) [6] dikembangkan oleh Thomas L. Saaty, AHP berfungsi untuk memecahkan masalah yang kompleks menjadi sub-sub masalah lalu menyusunnya ke dalam bentuk hirarki.

a. Identifikasi Tujuan

Tujuan menggunakan metode AHP yaitu melihat suatu level tertinggi yang berasal dari struktur hirarki untuk pemilihan pegawai terbaik pada Klinik Yadika Petukangan. Sehingga memperoleh nilai bobot dari masing-masing kriteria yang sudah ditentukan oleh Klinik Yadika Petukangan. Struktur hirarki Klinik Yadika Petukangan dapat dilihat pada Gambar 4 sebagai berikut :

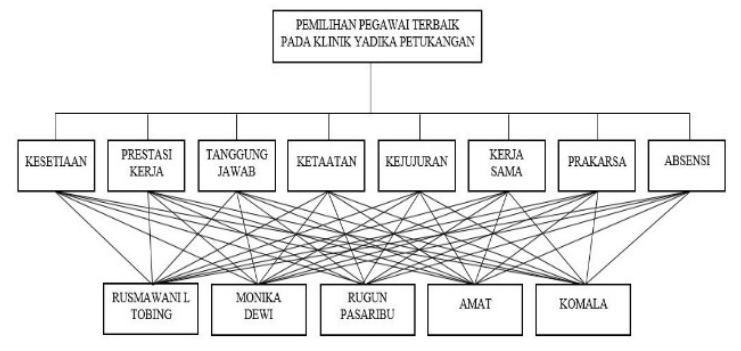

Gambar 4. Struktur Hirarki Pemilihan Pegawai Terbaik

b. Identifikasi Kriteria

Kriteria yang ditentukan oleh Klinik Yadika Petukangan dibagi menjadi 8 (delapan) yang dapat dilihat pada Tabel 1 sebagai berikut :

Tabel 1. Bobot Kriteria

\begin{tabular}{ll}
\hline Kode Kriteria & Nama Kriteria \\
\hline KRT1 & Kesetiaan \\
KRT2 & Prestasi Kerja \\
KRT3 & Tanggung Jawab \\
KRT4 & Ketaatan \\
KRT5 & Kejujuran \\
KRT6 & Kerja Sama \\
KRT7 & Prakarsa \\
KRT8 & Absensi \\
\hline
\end{tabular}

c. Pengolahan Data Analytical Hierarchy Process (AHP)

Pengolahan data pada metode AHP yaitu, perbandingan kriteria yang telah diajukan kepada responden ahli maka didapat kan tabel matriks perbandingan kriteria yang dapat dilihat pada Tabel 2 sebagai berikut :

Tabel 2. Bobot Kriteria

\begin{tabular}{lcccccccc}
\hline \multicolumn{1}{l}{ Kriteria KRT } & \multicolumn{1}{c}{ KRT2 } & KRT3 & KRT4 & KRT5 & KRT6 KRT7 KRT8 \\
\hline KRT1 & 1 & $1 / 2$ & $1 / 2$ & $1 / 2$ & $1 / 2$ & 1 & 1 & $1 / 2$ \\
KRT2 & 2 & 1 & $1 / 2$ & $1 / 2$ & $1 / 3$ & $1 / 2$ & 1 & $1 / 2$ \\
KRT3 & 2 & 2 & 1 & $1 / 2$ & $1 / 3$ & 2 & 2 & 1 \\
KRT4 & 2 & 2 & 2 & 1 & $1 / 3$ & 2 & 2 & 2
\end{tabular}




\begin{tabular}{lllcccccc} 
KRT5 & 2 & 3 & 3 & 3 & 1 & 3 & 2 & 3 \\
KRT6 & 1 & 2 & $1 / 2$ & $1 / 2$ & $1 / 3$ & 1 & 2 & $1 / 2$ \\
KRT7 & 1 & 1 & $1 / 2$ & $1 / 2$ & $1 / 2$ & $1 / 2$ & 1 & 1 \\
KRT8 & 2 & 2 & 1 & $1 / 2$ & $1 / 3$ & 2 & 1 & 1 \\
\hline
\end{tabular}

\section{d. Pengujian Metode Analytical Hierarchy Process (AHP)}

Pengujian model Analytical Hierarchy Process (AHP) dilakukan dengan cara menghitung nilai Consisten Index (CI) menggunakan rumus dengan proses sebagai berikut :

$$
\begin{aligned}
& C I=\frac{(\pi-n)}{n-1} \\
& \mathrm{n}=\text { Banyaknya alternatif }
\end{aligned}
$$

$$
C I=\frac{(8,4286-8)}{8-7}=0,0612
$$

Kemudian menghitung Consistency Ratio (CR), dubutuhkan nilai Random Index (RI) yang didapat dari tabel Oarkridge.

$$
\begin{aligned}
C R & =\frac{C I}{R I} \\
C R & =\frac{0,0612}{1,41}=0,0434
\end{aligned}
$$

Penilaian perbandingan dikatakan konsisten jika CR ridak lebih dari 0.10 sehingga penilaian perbandingan kriteria pegawai terbaik pada Klinik Yadika Petukangan Sudah Konsisten dan tidak memerlukan revisi penilaian.

\subsection{Metode Multi-Objective Optimization On The Basis Of Ratio Analysis (MOORA)}

Metode MOORA [7] juga memiliki tingkat selektifitas yang baik karena dapat menentukan tujuan dan kriteria yang bertentangan, yaitu kriteria yang bernilai menguntungkan (Benefit) atau yang tidak menguntungkan (Cost).

a. Pengolahan Data Multi Objective Optimization On The Basis Of Ratio Analysis (MOORA)

Sebelum menghitung matriks normalisasi, harus diketahui nilai masing-masing alternatif yang didapat dari Bagian HRD berdasarkan data rekapitulasi daftar penilaian pelaksanaan pekerja (DP3) yang dapat dilihat pada Tabel 3 sebagai berikut :

Tabel 3. Nilai Alternatif Setiap Kriteria

\begin{tabular}{lccccccccc}
\hline \multirow{2}{*}{ Altnf } & \multicolumn{10}{c}{ Kriteria } \\
\cline { 2 - 10 } & KRT & KRT & KRT & KRT & KRT & KRT & KRT & KRT \\
& $\mathbf{1}$ & $\mathbf{2}$ & $\mathbf{3}$ & $\mathbf{4}$ & $\mathbf{5}$ & $\mathbf{6}$ & $\mathbf{7}$ & $\mathbf{8}$ \\
\hline Monika & 93 & 87 & 80 & 79 & 88 & 82 & 82 & 23,25 \\
Amat & 87 & 88 & 90 & 82 & 93 & 79 & 94 & 23,91 \\
Rusma & 90 & 88 & 87 & 79 & 93 & 81 & 90 & 23,5 \\
Komala & 90 & 89 & 80 & 78 & 89 & 81 & 89 & 23,75 \\
Rugun & 80 & 91 & 77 & 81 & 90 & 78 & 90 & 23,25 \\
\hline
\end{tabular}

Setelah mengetahui nilai alternatif pada masing-masing kriteria, Selanjutnya melakukan pembentukan matriks keputusan sebagai berikut :

$\begin{array}{lllllllc}93 & 87 & 80 & 79 & 88 & 82 & 82 & 23,25 \\ 87 & 88 & 90 & 82 & 93 & 79 & 94 & 23,91 \\ 90 & 88 & 87 & 79 & 93 & 81 & 90 & 23,5 \\ 90 & 89 & 80 & 78 & 89 & 81 & 89 & 23,75 \\ 80 & 91 & 77 & 81 & 90 & 78 & 90 & 23,25\end{array}$

Kemudian setelah melakukan pembentukan matriks keputusan, peneliti menentukan matriks normalisasi kriteria untuk menghitung nilai masingmasing alternatif dari setiap kriteria sebagai berikut :

1) Melakukan perhitungan matriks pada kriteria Kesetiaan.

$$
\begin{aligned}
& X_{11}=\frac{X_{11}}{\sqrt{X_{11}{ }^{2}+X_{21}{ }^{2}+X_{31}{ }^{2}+X_{41}{ }^{2}+X_{51}{ }^{2}}} \\
& X_{11}=\frac{93}{\sqrt{93^{2}+87^{2}+90^{2}+90^{2}+80^{2}}}=\frac{93}{\sqrt{38818}}=0,472
\end{aligned}
$$

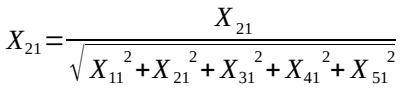

$$
\begin{aligned}
& X_{21}=\frac{87}{\sqrt{93^{2}+87^{2}+90^{2}+90^{2}+80^{2}}}=\frac{87}{\sqrt{38818}}=0,442 \\
& X_{31}=\frac{X_{31}}{\sqrt{X_{11}{ }^{2}+X_{21}{ }^{2}+X_{31}{ }^{2}+X_{41}{ }^{2}+X_{51}{ }^{2}}} \\
& X_{31}=\frac{90}{\sqrt{93^{2}+87^{2}+90^{2}+90^{2}+80^{2}}}=\frac{90}{\sqrt{38818}}=0,457 \\
& X_{41}=\frac{X_{41}}{\sqrt{X_{11}{ }^{2}+X_{21}{ }^{2}+X_{31}{ }^{2}+X_{41}{ }^{2}+X_{51}^{2}}} \\
& X_{41}=\frac{90}{\sqrt{93^{2}+87^{2}+90^{2}+90^{2}+80^{2}}}=\frac{90}{\sqrt{38818}}=0,457 \\
& X_{51}=\frac{X_{51}}{\sqrt{X_{11}{ }^{2}+X_{21}{ }^{2}+X_{31}{ }^{2}+X_{41}{ }^{2}+X_{51}{ }^{2}}} \\
& X_{51}=\frac{80}{\sqrt{93^{2}+87^{2}+90^{2}+90^{2}+80^{2}}}=\frac{80}{\sqrt{38818}}=0,406
\end{aligned}
$$

2) Melakukan perhitungan matriks pada kriteria Prestasi Kerja.

$$
\begin{aligned}
& X_{12}=\frac{X_{12}}{\sqrt{X_{12}{ }^{2}+X_{22}{ }^{2}+X_{32}{ }^{2}+X_{42}{ }^{2}+X_{52}^{2}}} \\
& X_{12}=\frac{87}{\sqrt{87^{2}+88^{2}+88^{2}+89^{2}+91^{2}}}=\frac{87}{\sqrt{39259}}=0,439 \\
& X_{22}=\frac{X_{22}}{\sqrt{X_{12}{ }^{2}+X_{22}{ }^{2}+X_{32}{ }^{2}+X_{42}{ }^{2}+X_{52}^{2}}}
\end{aligned}
$$




$$
\begin{aligned}
& X_{22}=\frac{88}{\sqrt{87^{2}+88^{2}+88^{2}+89^{2}+91^{2}}}=\frac{88}{\sqrt{39259}}=0,444
\end{aligned}
$$

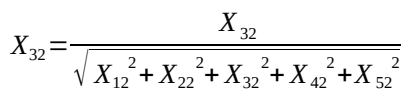

$$
\begin{aligned}
& X_{32}=\frac{88}{\sqrt{87^{2}+88^{2}+88^{2}+89^{2}+91^{2}}}=\frac{88}{\sqrt{39259}}=0,444
\end{aligned}
$$

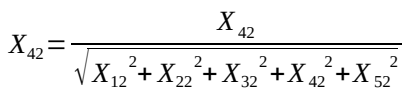

$$
\begin{aligned}
& X_{42}=\frac{89}{\sqrt{87^{2}+88^{2}+88^{2}+89^{2}+91^{2}}}=\frac{89}{\sqrt{39259}}=0,449
\end{aligned}
$$

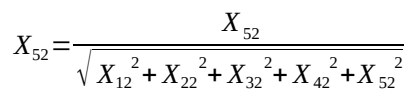

$$
\begin{aligned}
& X_{52}=\frac{91}{\sqrt{87^{2}+88^{2}+88^{2}+89^{2}+91^{2}}}=\frac{91}{\sqrt{39259}}=0,459
\end{aligned}
$$

3) Melakukan perhitungan matriks pada kriteria Tanggung Jawab.

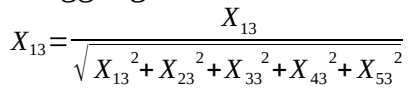

$$
\begin{aligned}
& X_{13}=\frac{80}{\sqrt{80^{2}+90^{2}+87^{2}+80^{2}+77^{2}}}=\frac{80}{\sqrt{34398}}=0,431
\end{aligned}
$$

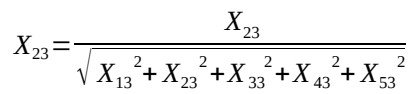$$
X_{23}=\frac{90}{\sqrt{80^{2}+90^{2}+87^{2}+80^{2}+77^{2}}}=\frac{90}{\sqrt{34398}}=0,485
$$

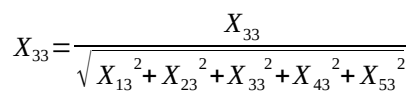$$
X_{33}=\frac{87}{\sqrt{80^{2}+90^{2}+87^{2}+80^{2}+77^{2}}}=\frac{87}{\sqrt{34398}}=0,469
$$

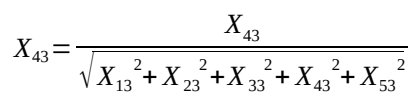$$
X_{43}=\frac{80}{\sqrt{80^{2}+90^{2}+87^{2}+80^{2}+77^{2}}}=\frac{80}{\sqrt{34398}}=0,431
$$

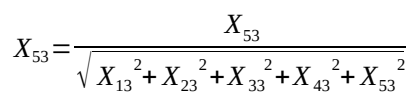$$
X_{53}=\frac{77}{\sqrt{80^{2}+90^{2}+87^{2}+80^{2}+77^{2}}}=\frac{77}{\sqrt{34398}}=0,415
$$

4) Melakukan perhitungan matriks pada kriteria Ketaatan.

$$
\begin{aligned}
& X_{14}=\frac{X_{14}}{\sqrt{X_{14}^{2}+X_{24}^{2}+X_{34}^{2}+X_{44}^{2}+X_{54}^{2}}} \\
& X_{14}=\frac{79}{\sqrt{79^{2}+82^{2}+79^{2}+78^{2}+81^{2}}}=\frac{79}{\sqrt{31851}}=0,443
\end{aligned}
$$

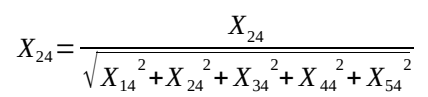

$$
\begin{aligned}
& X_{24}=\frac{82}{\sqrt{79^{2}+82^{2}+79^{2}+78^{2}+81^{2}}}=\frac{82}{\sqrt{31851}}=0,459 \\
& X_{34}=\frac{X_{34}}{\sqrt{X_{14}{ }^{2}+X_{24}{ }^{2}+X_{34}{ }^{2}+X_{44}{ }^{2}+X_{54}{ }^{2}}} \\
& X_{34}=\frac{79}{\sqrt{79^{2}+82^{2}+79^{2}+78^{2}+81^{2}}}=\frac{79}{\sqrt{31851}}=0,443 \\
& X_{44}=\frac{X_{44}}{\sqrt{X_{14}{ }^{2}+X_{24}{ }^{2}+X_{34}{ }^{2}+X_{44}{ }^{2}+X_{54}{ }^{2}}} \\
& X_{44}=\frac{78}{\sqrt{79^{2}+82^{2}+79^{2}+78^{2}+81^{2}}}=\frac{78}{\sqrt{31851}}=0,437
\end{aligned}
$$

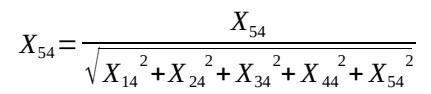

$$
\begin{aligned}
& X_{54}=\frac{81}{\sqrt{79^{2}+82^{2}+79^{2}+78^{2}+81^{2}}}=\frac{81}{\sqrt{31851}}=0,454
\end{aligned}
$$

5) Melakukan perhitungan matriks pada kriteria Kejujuran.

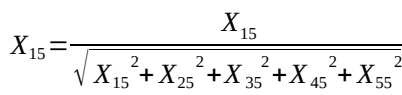

$$
\begin{aligned}
& X_{15}=\frac{88}{\sqrt{88^{2}+93^{2}+93^{2}+89^{2}+90^{2}}}=\frac{88}{\sqrt{41063}}=0,434
\end{aligned}
$$

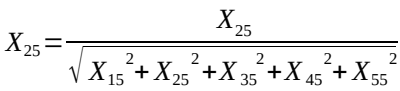

$$
\begin{aligned}
& X_{25}=\frac{93}{\sqrt{88^{2}+93^{2}+93^{2}+89^{2}+90^{2}}}=\frac{93}{\sqrt{41063}}=0,459
\end{aligned}
$$

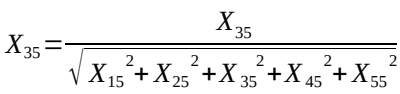

$$
\begin{aligned}
& X_{35}=\frac{93}{\sqrt{88^{2}+93^{2}+93^{2}+89^{2}+90^{2}}}=\frac{93}{\sqrt{41063}}=0,459
\end{aligned}
$$

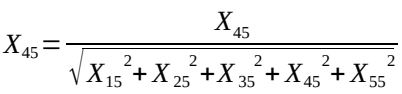$$
X_{45}=\frac{89}{\sqrt{88^{2}+93^{2}+93^{2}+89^{2}+90^{2}}}=\frac{89}{\sqrt{41063}}=0,439
$$ 


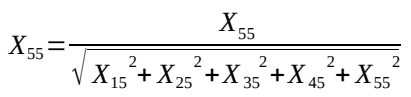

$$
\begin{aligned}
& X_{55}=\frac{90}{\sqrt{88^{2}+93^{2}+93^{2}+89^{2}+90^{2}}}=\frac{90}{\sqrt{41063}}=0,444
\end{aligned}
$$

6) Melakukan perhitungan matriks pada kriteria Kerja Sama.

$$
\begin{aligned}
& X_{16}=\frac{X_{16}}{\sqrt{X_{16}{ }^{2}+X_{26}{ }^{2}+X_{36}{ }^{2}+X_{46}{ }^{2}+X_{56}{ }^{2}}} \\
& X_{16}=\frac{82}{\sqrt{82^{2}+79^{2}+81^{2}+81^{2}+78^{2}}}=\frac{82}{\sqrt{32171}}=0,457 \\
& X_{26}=\frac{X_{26}}{\sqrt{X_{16}{ }^{2}+X_{26}{ }^{2}+X_{36}{ }^{2}+X_{46}{ }^{2}+X_{56}^{2}}} \\
& X_{26}=\frac{79}{\sqrt{82^{2}+79^{2}+81^{2}+81^{2}+78^{2}}}=\frac{79}{\sqrt{32171}}=0,440
\end{aligned}
$$

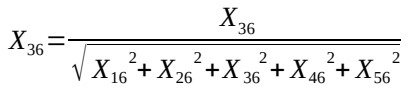

$$
\begin{aligned}
& X_{36}=\frac{81}{\sqrt{82^{2}+79^{2}+81^{2}+81^{2}+78^{2}}}=\frac{81}{\sqrt{32171}}=0,452 \\
& X_{46}=\frac{X_{46}}{\sqrt{X_{16}{ }^{2}+X_{26}{ }^{2}+X_{36}{ }^{2}+X_{46}{ }^{2}+X_{56}^{2}}} \\
& X_{46}=\frac{81}{\sqrt{82^{2}+79^{2}+81^{2}+81^{2}+78^{2}}}=\frac{81}{\sqrt{32171}}=0,452
\end{aligned}
$$

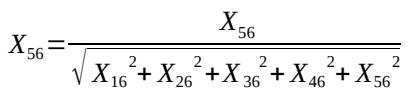

$$
\begin{aligned}
& X_{56}=\frac{78}{\sqrt{82^{2}+79^{2}+81^{2}+81^{2}+78^{2}}}=\frac{78}{\sqrt{32171}}=0,435
\end{aligned}
$$

7) Melakukan perhitungan matriks pada kriteria Prakarsa.

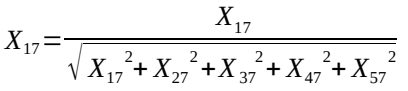

$$
\begin{aligned}
& X_{17}=\frac{82}{\sqrt{82^{2}+94^{2}+90^{2}+89^{2}+90^{2}}}=\frac{82}{\sqrt{39681}}=0,412
\end{aligned}
$$

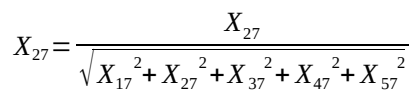

$$
\begin{aligned}
& X_{27}=\frac{94}{\sqrt{82^{2}+94^{2}+90^{2}+89^{2}+90^{2}}}=\frac{94}{\sqrt{39681}}=0,472
\end{aligned}
$$

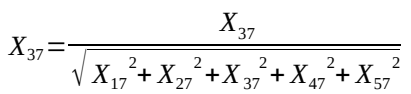

$$
\begin{aligned}
& X_{37}=\frac{90}{\sqrt{82^{2}+94^{2}+90^{2}+89^{2}+90^{2}}}=\frac{90}{\sqrt{39681}}=0,452
\end{aligned}
$$

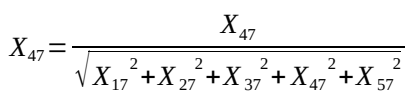

$$
\begin{aligned}
& X_{47}=\frac{89}{\sqrt{82^{2}+94^{2}+90^{2}+89^{2}+90^{2}}}=\frac{89}{\sqrt{39681}}=0,447
\end{aligned}
$$

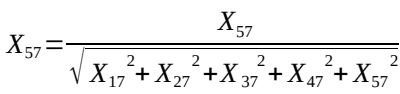

$$
\begin{aligned}
& X_{57}=\frac{90}{\sqrt{82^{2}+94^{2}+90^{2}+89^{2}+90^{2}}}=\frac{90}{\sqrt{39681}}=0,452
\end{aligned}
$$

8) Melakukan perhitungan matriks pada kriteria Absensi.

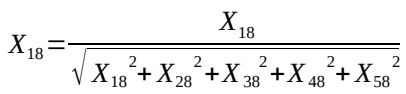

$$
\begin{aligned}
& X_{18}=\frac{23,25}{\sqrt{23,25^{2}+23,91^{2}+23,5^{2}+23,75^{2}+23,25^{2}}} \\
& X_{18}=\frac{23,25}{\sqrt{2769,11}}=0,442
\end{aligned}
$$

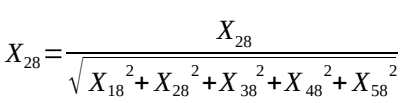

$$
\begin{aligned}
& X_{28}=\frac{23,91}{\sqrt{23,25^{2}+23,91^{2}+23,5^{2}+23,75^{2}+23,25^{2}}} \\
& X_{28}=\frac{23,91}{\sqrt{2769,11}}=0,454 \\
& X_{38}=\frac{X_{38}}{\sqrt{X_{18}{ }^{2}+X_{28}{ }^{2}+X_{38}{ }^{2}+X_{48}{ }^{2}+X_{58}^{2}}} \\
& X_{38}=\frac{23,5}{\sqrt{23,25^{2}+23,91^{2}+23,5^{2}+23,75^{2}+23,25^{2}}} \\
& X_{38}=\frac{23,5}{\sqrt{2769,11}}=0,447 \\
& X_{48}=\frac{X_{48}}{\sqrt{X_{18}{ }^{2}+X_{28}{ }^{2}+X_{38}{ }^{2}+X_{48}{ }^{2}+X_{58}^{2}}} \\
& X_{48}=\frac{23,75}{\sqrt{23,25^{2}+23,91^{2}+23,5^{2}+23,75^{2}+23,25^{2}}} \\
& X_{48}=\frac{23,75}{\sqrt{2769,11}}=0,451
\end{aligned}
$$

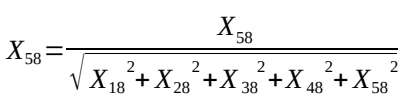

$$
\begin{aligned}
& X_{58}=\frac{23,25}{\sqrt{23,25^{2}+23,91^{2}+23,5^{2}+23,75^{2}+23,25^{2}}}
\end{aligned}
$$




$$
X_{58}=\frac{23,25}{\sqrt{2769,11}}=0,442
$$

Setelah mendapatkan hasil perhitungan matriks normalisasi, selanjutnya melakukan perhitungan nilai altrernatif yang sudah dinormalisasi, kemudian dilakukan perkalian bobot kriteria yang dapat dilihat pada Tabel 4 sebagai berikut :

Tabel 4. Nilai Matriks Normalisasi

\begin{tabular}{lcccccccc}
\hline \multirow{3}{*}{ Altnf } & \multicolumn{7}{c}{ Kriteria } \\
\cline { 2 - 9 } & KRT & KRT & KRT & KRT & KRT & KRT & KRT & KRT \\
& $\mathbf{1}$ & $\mathbf{2}$ & $\mathbf{3}$ & $\mathbf{4}$ & $\mathbf{5}$ & $\mathbf{6}$ & $\mathbf{7}$ & $\mathbf{8}$ \\
\hline Monika & 0,472 & 0,439 & 0,431 & 0,443 & 0,434 & 0,457 & 0,412 & 0,442 \\
Amat & 0,442 & 0,444 & 0,485 & 0,459 & 0,459 & 0,440 & 0,472 & 0,454 \\
Rusma & 0,457 & 0,444 & 0,469 & 0,443 & 0,459 & 0,452 & 0,452 & 0,447 \\
Komala & 0,457 & 0,449 & 0,431 & 0,437 & 0,439 & 0,452 & 0,447 & 0,451 \\
Rugun & 0,406 & 0,459 & 0,415 & 0,454 & 0,444 & 0,435 & 0,452 & 0,442 \\
Bobot & $\mathbf{0 , 0 7 2 7}$ & $\mathbf{0 , 0 7 4 8}$ & $\mathbf{0 , 1 2 5 4 0 , 1 6 5 5 0 , 2 7 5 5 0 , 0 9 0 6 0 , 0 7 8 9 0 , 1 1 6 6}$ \\
\hline
\end{tabular}

Setelah melakukan hasil perkalian bobot kriteria dengan masing-masing nilai alternatif, selanjutnya adalah perhitungan menentukan nilai yi, untuk alternatif terbaik memiliki nilai yi tertinggi dan untuk alternatif terburuk memiliki nilai yi terendah. Nilai Yi untuk menentukan alternatif terbaik dapat dilihat pada Tabel 5 sebagai berikut :

Tabel 5. Perhitungan Nilai Yi

\begin{tabular}{llll}
\hline Altnf & $\begin{array}{l}\text { Max } \\
\text { (KRT1 + KRT2 + KRT3+ } \\
\text { KRT4 +KRT5 + KRT6 + }\end{array}$ & $\begin{array}{l}\text { Min } \\
\mathbf{( 0 )}\end{array}$ & Yi = Max - Min \\
& KRT7 + KRT8) & \\
\hline Monika & $0,0343+0,0328+0,0540+0,0733$ & \\
& $+0,1196+$ & & \\
& $0,0414+0,0325+0,0515$ & 0 & 0,4394 \\
Amat & $0,0321+0,0332+0,0608+0,0760$ & \\
& $+0,1264+$ & 0 & 0,4586 \\
Rusma & $0,0399+0,0372+0,0530$ & \\
& $0,0332+0,0332+0,0589+0,0733$ & \\
& $+0,1264+$ & 0 & 0,4538 \\
Komala & $0,0410+0,0357+0,0521$ & \\
& $0,0332+0,0336+0,0540+0,0723$ & \\
& $+0,1210+$ & 0 & 0,4429 \\
Rugun & $0,0409+0,0353+0,0526$ & $0,0295+0,0343+0,0520+0,0751$ & \\
& $+0,1223+$ & 0 & 0,4398 \\
\hline
\end{tabular}

Berdasarkan perhitungan dengan menggunakan metode MOORA untuk memperoleh hasil rangking maka diperoleh nilai alternatif tertinggi pegawai Klinik Yadika Petukangan yang dapat dilihat pada Tabel 6 sebagai berikut :

Tabel 6. Hasil Perangkingan

\begin{tabular}{lccc}
\hline \multicolumn{1}{c}{ Nama Pegawai } & Yi & Ranking \\
\hline Amat & Rusma & 0,4586 & 1 \\
\multicolumn{1}{c}{ Nama Pegawai } & 0,4538 & 2 \\
Komala & Yi & Ranking \\
Rugun & 0,4429 & 3 \\
Monika & 0,4398 & 4 \\
\hline
\end{tabular}

Dalam proses pemilihan pegawai terbaik pada Klinik Yadika Petukangan, dapat disimpulkan bahwa nilai tertinggi diperoleh Amat dengan nilai 0,04586.

\subsection{Model Data}

a. Entity Relationship Diagram (ERD)

Model ini dirancang untuk keperluan pengembangan Sistem Penunjang Keputusan Pemilihan Pegawai Terbaik pada Klinik Yadika Petukangan. Sebuah rancangan model basis data ditunjukkan menggunakan Entity Relationship Diagram (ERD) yang dapat dilihat pada Gambar 5.

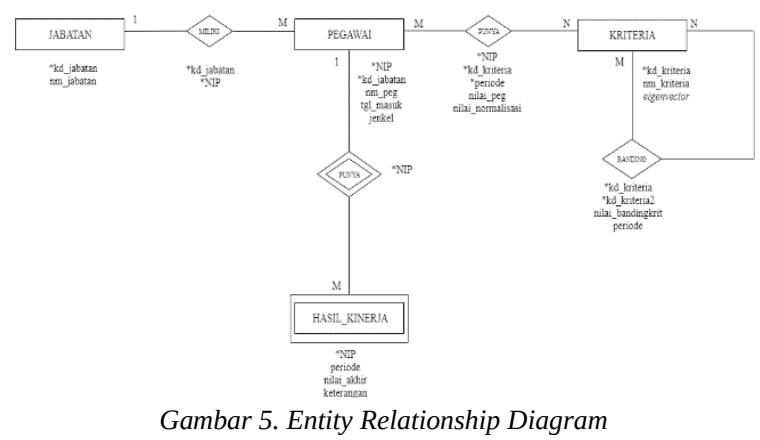

b. Logical Record Structure (LRS)

Setelah di transformasikan ERD ke LRS, maka bentuk logical record structure (LRS) yang sudah terbentuk yang dapat dilihat pada Gambar 6.

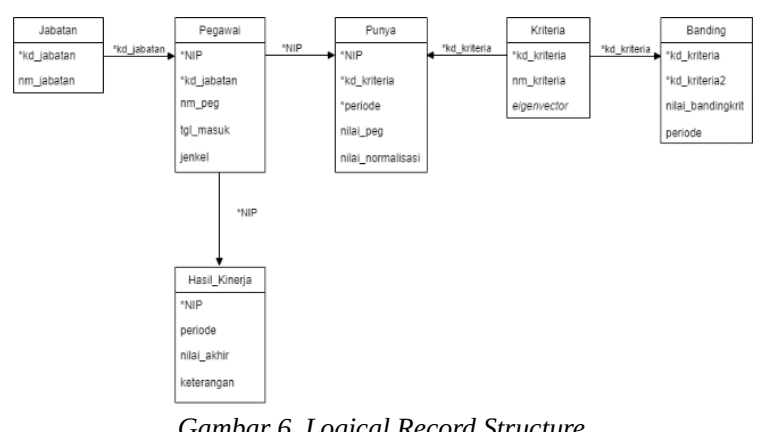

Gambar 6. Logical Record Structure

\subsection{Rancangan Layar}

a. Rancangan Layar Menu Entri Data Pegawai Rancangan layar menu entri data pegawai dapat dilihat pada Gambar 7. 


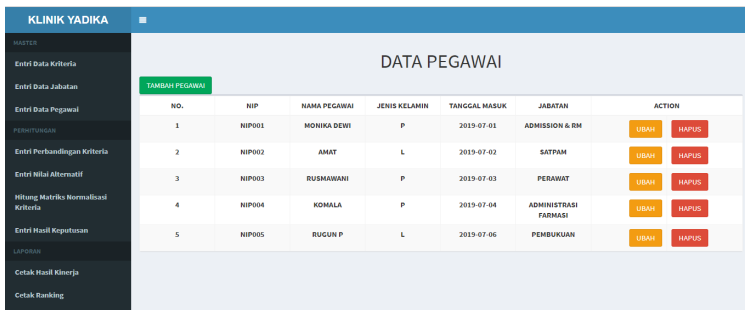

Gambar 7. Rancangan Layar Menu Entri Data Pegawai

b. Rancangan Layar Menu Entri Perbandingan Kriteria

Rancangan layar menu entri perbandingan kriteria dapat dilihat pada Gambar 8.

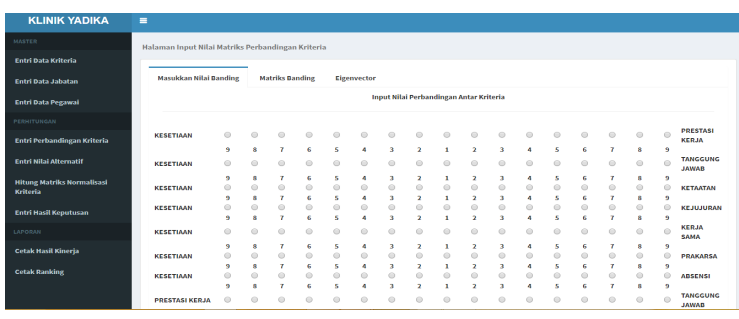

Gambar 8. Rancangan Layar Menu Entri Perbandingan Kriteria

c. Rancangan Layar Menu Entri Nilai Alternatif

Rancangan layar menu entri nilai alternatif dapat dilihat pada Gambar 9.

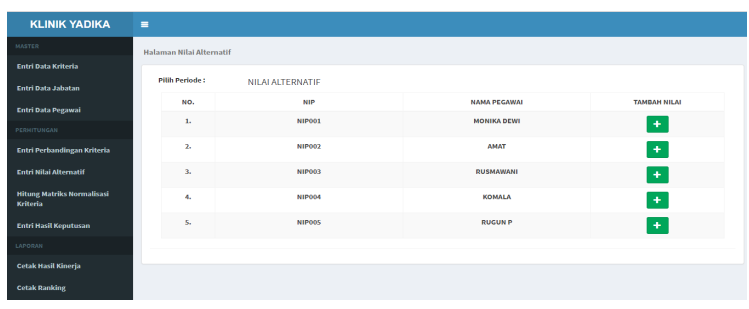

Gambar 9. Rancangan Layar Menu Entri Nilai Alternatif

d. Rancangan Layar Menu Entri Hasil Keputusan

Rancangan layar menu entri hasil keputusan dapat dilihat pada Gambar 10.

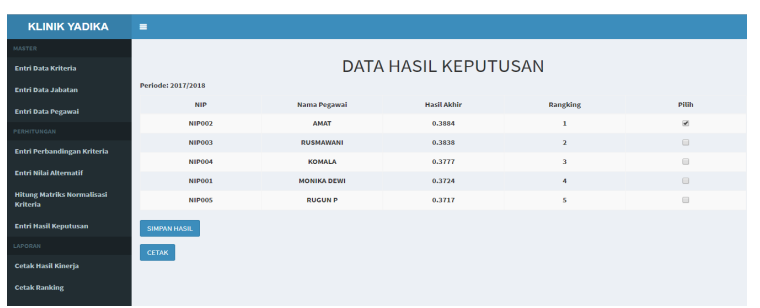

Gambar 10. Rancangan Layar Menu Entri Hasil Keputusan

\subsection{Hasil Penelitian}

Berdasarkan perhitungan dengan menggunakan metode Analytical Hierarchy Process (AHP) dan Multi Objective Optimization On The Basis Of Ratio Analysis (MOORA) maka diperoleh nilai alternatif yang dapat dilihat pada Tabel 7.
Tabel 7. Hasil Penelitian

\begin{tabular}{lcc}
\hline \multicolumn{1}{c}{ Nama Pegawai } & Yi & Ranking \\
\hline Amat & 0,4586 & 1 \\
Rusma & 0,4538 & 2 \\
Komala & 0,4429 & 3 \\
Rugun & 0,4398 & 4 \\
Monika & 0,4394 & 5 \\
\hline
\end{tabular}

Dalam proses pemilihan pegawai terbaik pada Klinik Yadika Petukangan, dapat disimpulkan bahwa nilai tertinggi diperoleh Amat dengan nilai 0,04586.

\section{KESIMPULAN}

Berdasarkan uraian dan analisa yang dilakukan oleh peneliti pada Klinik Yadika Petukangan, maka dapat ditarik kesimpulan. Dengan adanya sistem penunjang keputusan ini maka dapat dilakukan proses dalam pemilihan pegawai terbaik dengan tepat sehingga proses pemilihan pegawai terbaik bersifat lebih obyektif dalam proses penilaiannya. Berdasarkan dokumen berjalan pemilihan pegawai terbaik, terdapat 8 (delapan) kriteria dengan masingmasing nilai eigenvector (bobot) yaitu kesetiaan dengan bobot 0,0727 , prestasi kerja dengan bobot 0,0748, tanggung jawab dengan bobot 0,1254 , ketaatan dengan bobot 0,1655, kejujuran dengan bobot 0,2755, kerja sama dengan bobot 0,0906, prakarsa dengan bobot 0,0789 dan absensi dengan bobot 0,1166. Dan nilai eigenvector tersebut sudah konsisten dan tidak perlu dilakukan perhitungan ulang, nilai Consistency Ratio yaitu 0,0434 dan dengan adanya sistem penunjang keputusan yang menggunakan metode Analytical Hierarchy Process (AHP) dan metode Multi-Objective Optimization On The Basis of Ratio Analysis (MOORA). Dapat membantu user dalam proses pemilihan pegawai terbaik pada Klinik Yadika Petukangan menjadi lebih cepat, mudah dan akurat.

\section{DAFTAR PUSTAKA}

[1] A. Suryana, E. Yulianto, and K. D. Pratama, "PENILAIAN PRESTASI PEGAWAI MENGGUNAKAN METODE,” J. Ilm. Teknol. Inf. Terap., vol. III, no. 2, pp. 130-139, 2017.

[2] M. Hasanudin, Y. Marli, and B. Hendriawan, "SISTEM PENDUKUNG KEPUTUSAN PEMILIHAN KARYAWAN TERBAIK MENGGUNAKAN METODE ANALYTICAL HIERARCHY PROCESS ( STUDI KASUS PADA PT . BANDO INDONESIA )," Semin. Nas. Teknol. Inf. dan Multimed. 2018, pp. 91-96, 2018.

[3] S. Manurung, "SISTEM PENDUKUNG KEPUTUSAN PEMILIHAN GURU DAN PEGAWAI TERBAIK MENGGUNAKAN METODE MOORA,” SIMETRIS, vol. 9, no. 1, pp. 701-706, 2018.

[4] A. Rafiqi, D. Riyansyah, and H. Sartika, "Sistem Pendukung Keputusan Penentuan Karyawan Terbaik 
Menggunakan Metode MOORA,” pp. 728-733, 2018.

[5] N. Riyadi and A. Widjaja, "BERORIENTASI OBYEK,” Telemat. MKOM, vol. 8, no. 2, pp. 153162, 2016.

[6] Diana, Metode Dan Aplikasi Sistem Pendukung Keputusan. 2018.

[7] S. Alvita, N. Intan, F. Syahputra, K. Ulfa, and G. L. Ginting, "Sistem Pendukung Keputusan Pemilihan Mekanik Sepeda Motor Terbaik Menggunakan Metode Multi Objective Optimization on The Basis of Ratio Analysis ( MOORA )," J. Ris. Komput., vol. 5, no. 1, pp. 66-70, 2018. 